\title{
Faktor Prognosis Kematian Sindrom Syok Dengue
}

\author{
Anggy Pangaribuan, Endy Paryanto Prawirohartono, Ida Safitri Laksanawati \\ Bagian Ilmu Kesehatan Anak RSUP Dr. Sardjito/Fakultas Kedokteran Universitas Gadjah Mada, \\ Yogyakarta
}

Latar belakang. Sindrom syok dengue (SSD) merupakan bentuk klinis yang paling berat dari demam berdarah dengue (DBD) dan mempunyai angka kematian yang tinggi. Prediktor kematian pada DSS masih berbeda-beda, sehingga sangat penting untuk meneliti faktor prognosis yang mempengaruhi kematian SSD pada anak.

Tujuan. Mengetahui faktor prognosis kematian anak dengan SSD.

Metode. Metode penelitian yang digunakan adalah kohort retrospektif. Subyek adalah pasien SSD sesuai kriteria WHO 1997 yang dirawat di Instalasi Kesehatan Anak RSUP Dr. Sardjito dari Januari 2006 - Juli 2012. Faktor prognosis yang diteliti adalah usia, jenis kelamin, status obesitas, tipe infeksi, keterlambatan berobat, manajemen cairan, derajat trombositopenia, koagulopati, perdarahan mayor, prolonged shock, ensefalopati, disfungsi hati, gagal hati fulminan, disseminated intravascular coagulation (DIC), edema paru dan hipoksemia. Analisis regresi Cox digunakan untuk mengetahui kemaknaan faktor prognosis kematian pada DSS.

Hasil. Selama periode Januari 2006 - Juli 2012 terdapat 221 pasien DSS dengan angka kematian 27\%. Sembilanpuluh enam pasien diikutkan dalam penelitian dan 33(34\%) subyek di antaranya meninggal. Analisis multivariat menunjukkan manajemen cairan sebelum masuk rumah sakit Dr. Sardjito yang tidak adekuat (HR 2,658; IK 95\% 1,146;6,616), perdarahan mayor (HR 8,223; IK 95\% 1,741;38,831) dan prolonged shock (HR 15,805; IK 95\% 3,486;71,660) merupakan faktor prognosis independen kematian pada anak dengan SSD.

Kesimpulan. Manajemen cairan sebelum masuk rumah sakit rujukan yang tidak adekuat, perdarahan mayor dan prolonged shock merupakan faktor prognosis independen kematian pada anak dengan SSD.

Sari Pediatri 2014;15(5):332-40.

Kata kunci: sindrom syok dengue, faktor prognosis, mortalitas

\footnotetext{
Alamat korespondensi:

Dr. Anggy Pangaribuan. Peserta Program Pendidikan Dokter Spesialis Ilmu Kesehatan Anak, Departemen Ilmu Kesehatan Anak FK UGMRSUP Dr. Sardjito, Jl. Kesehatan No.1 Sekip Yogyakarta 55284, Telp. (0274) 587333/587832, Fax. (0274) 565639/515408. E-mail: dr.anggypangaribuan@gmail.com
}

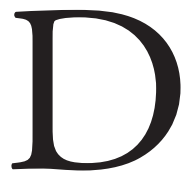

emam dengue merupakan penyakit infeksi virus yang ditularkan melalui gigitan nyamuk Aedes aegypti dan Aedes albopictus. Empat serotipe penyebab virus dengue, yaitu DEN 1, 2, 3, dan 4 dengan morbiditas 
dan mortalitas yang tinggi di banyak daerah di dunia. Virus dengue dapat menyebabkan manifestasi klinis yang bermacam-macam dari asimptomatik sampai demam berdarah dengue (DBD) dengan kebocoran plasma yang dapat mengakibatkan syok hipovolemik yaitu sindrom syok dengue (SSD). ${ }^{1-3}$

Angka kematian (case fatality rate) $\mathrm{DBD}$ di Indonesia menurun dengan stabil dari $41 \%$ pada tahun 1968 menjadi kurang dari 2\% sejak tahun 2000 , penurunan $1,21 \%$ pada tahun 2004, dan menjadi 0,86\% pada tahun $2008 .{ }^{4,5}$ Namun, angka kematian akibat SSD yang disertai dengan perdarahan gastrointestinal hebat dan ensefalopati masih tetap tinggi. Rampengan pada tahun 1986 melaporkan kejadian syok di Manado sebesar 60\% dari seluruh pasien DBD dengan angka kematian 6,6\%. Prevalensi syok $16 \%-40 \%$ pada hampir di seluruh rumah sakit di Indonesia dengan angka kematian 5,7\%-50\% pada tahun $1996 .^{6}$

Patogenesis utama yang menyebabkan kematian pada hampir seluruh pasien DBD adalah syok karena kebocoran plasma. Penanganan yang tepat dan sedini mungkin terhadap pasien presyok dan syok merupakan faktor penting yang menentukan hasil pengobatan. ${ }^{6}$ Beberapa penelitian telah dilakukan untuk mengidentifikasi faktor risiko kematian. Penelitian yang dilakukan di India menyebutkan bahwa syok refrakter berat, disseminated intravascular coagulation (DIC), acute respiratory distress syndrome (ARDS), gagal hati, manifestasi neurologis merupakan penyebab kematian pada DSS. ${ }^{7}$ Dhoria $\mathrm{dkk}^{8}$ pada tahun 2008 menunjukkan bahwa refractory shock dan koagulopati penyebab kematian pada DBD di India. Penelitian di Semarang pada anak dengan DSS, ditunjukkan bahwa efusi pleura bilateral dan aktivasi koagulasi berhubungan dengan kematian pada pasien DSS. ${ }^{9}$ Berdasarkan hasil beberapa penelitian, faktor yang memengaruhi kematian pada pasien DSS berbeda, maka perlu dilakukan penelitian di RSUP Dr. Sardjito untuk mengetahui faktor prognosis yang memengaruhi kematian pada pasien DBD dengan syok.

\section{Metode}

Telah dilakukan penelitian retrospektif pada pasien DSS dengan menggunakan data rekam medis RSUP Dr Sardjito Yogyakarta yang dirawat mulai Januari 2006 hingga Juli 2012. Kriteria inklusi adalah pasien
DSS usia 0-18 tahun yang memenuhi kriteria WHO 1997. Besar sampel penelitian dihitung menggunakan rumus besar sampel untuk studi kohort. Nilai kesalahan tipe I ditetapkan 5\%, nilai kesalahan tipe II $20 \%$, dan power penelitian $80 \%$. Berdasarkan penelitian sebelumnya kejadian kematian anak dengan jenis kelamin perempuan pada DSS adalah $51 \%(\mathrm{RR}=1,51)$, maka besar sampel yang diperlukan berdasarkan asumsi adalah 96. Sampel dipilih secara acak dari seluruh pasien DSS yang dirawat di Instalasi Kesehatan Anak RSUP Dr. Sardjito Yogyakarta berdasarkan kriteria inklusi dan eksklusi. Dilakukan pengelompokan pasien menjadi dua, terpapar faktor risiko dan tidak terpapar faktor risiko. Luaran masingmasing kelompok dinilai berdasarkan meninggal atau hidup. Faktor-faktor prognosis yang diteliti ialah usia, jenis kelamin, status nutrisi, tipe infeksi, keterlambatan berobat, manajemen cairan, derajat trombositopenia, koagulopati, perdarahan mayor, prolonged shock, ensefalopati, disfungsi hati, gagal hati fulminan, DIC, edema paru, hipoksemia.

Analisis data dilakukan dengan menggunakan program statistik SPSS versi 16. Analisis regresi Cox bivariat dilakukan untuk mencari hazard ratio dari tiap variabel prognosis yang berdasarkan uji Kaplan Meier dianggap memenuhi asumsi proportional hazard, yaitu variabel yang pada kurva Kaplan Meier tidak memiliki garis kesintasan yang saling berpotongan. Analisis multivariat dilakukan terhadap variabel yang mempunyai nilai $\mathrm{p}<0,25$ dalam analisis bivariat dan bermakna secara klinis dengan menggunakan analisis regresi Cox. Nilai $\mathrm{p}<0,05$ dianggap bermakna dengan $95 \%$ interval kepercayaan.

\section{Hasil}

Diperoleh 221 kasus DSS dengan angka kematian 59/221 (27\%) dari data rekam medis bulan Januari 2006 - Juli 2012. Angka kematian per tahun mulai dari tahun 2006 berturut-turut adalah 18/26 (69\%), 8/13 (62\%), 8/42 (19\%), 9/42 (21\%), 11/78 (14\%), 2/13 (15\%), 3/7(43\%). Dari 96 kasus DSS terdapat 32\% usia $\leq 5$ tahun dan $51 \%$ berjenis kelamin perempuan. Pasien DSS usia $\geq 5$ tahun (51\%) dan perempuan (64\%) lebih banyak yang meninggal. Terdapat 77\% kasus DSS rujukan, 91\% kasus rujukan meninggal. Mayoritas pasien DSS berasal dari Kodya. Sebanyak $37 \%$ pasien DSS masuk rumah sakit pada saat demam 
Tabel 1. Karakteristik dasar 63 kasus DSS hidup dan 33 kasus DSS meninggal

\begin{tabular}{|c|c|c|c|}
\hline Karakteristik dasar & $\begin{array}{l}\text { Meninggal } \\
(\mathrm{n}=33)\end{array}$ & $\begin{array}{l}\text { Hidup } \\
(\mathrm{n}=63)\end{array}$ & $\begin{array}{c}\text { Total } \\
(\mathrm{n}=96)\end{array}$ \\
\hline \multicolumn{4}{|l|}{ Usia, tahun, $\mathrm{n}(\%)$} \\
\hline$<5$ & $16(49)$ & $15(24)$ & $31(32)$ \\
\hline$\geq 5$ & $17(51)$ & $48(76)$ & $65(68)$ \\
\hline \multicolumn{4}{|l|}{ Jenis kelamin, n (\%) } \\
\hline Perempuan & $21(64)$ & $28(44)$ & $49(51)$ \\
\hline Laki-laki & $12(36)$ & $35(56)$ & $47(49)$ \\
\hline \multicolumn{4}{|l|}{ Tempat tinggal, n (\%) } \\
\hline Kodya & $12(37)$ & $23(37)$ & $35(37)$ \\
\hline Sleman & $3(9)$ & $12(19)$ & $15(16)$ \\
\hline Bantul & $11(33)$ & $16(25)$ & $27(28)$ \\
\hline Kulon Progo & $0(0)$ & $0(0)$ & $0(0)$ \\
\hline Gunung Kidul & $4(12)$ & $2(3)$ & $6(6)$ \\
\hline Luar kota & $3(9)$ & $10(16)$ & $13(13)$ \\
\hline \multicolumn{4}{|c|}{ Hari demam saat masuk rumah sakit, $\mathrm{n}(\%)$} \\
\hline 3 & $4(12)$ & $2(3)$ & $6(6)$ \\
\hline 4 & $12(36)$ & $22(35)$ & $34(35)$ \\
\hline 5 & $12(36)$ & $23(37)$ & $35(37)$ \\
\hline 6 & $5(15)$ & $15(24)$ & $20(21)$ \\
\hline 7 & $0(0)$ & $1(2)$ & $1(1)$ \\
\hline \multicolumn{4}{|l|}{ Rujukan, n (\%) } \\
\hline Ya & $30(91)$ & $44(70)$ & $74(77)$ \\
\hline Tidak & $3(9)$ & $19(30)$ & $22(23)$ \\
\hline \multicolumn{4}{|c|}{ Tingkat pendidikan ayah, n (\%) } \\
\hline Tidak sekolah & $0(0)$ & $0(0)$ & $0(0)$ \\
\hline SD & $4(12)$ & $11(18)$ & $15(16)$ \\
\hline SLTP & $5(15)$ & $10(16)$ & $15(16)$ \\
\hline SLTA & $13(39)$ & $21(33)$ & $34(35)$ \\
\hline D3 & $2(6)$ & $0(0)$ & $2(2)$ \\
\hline Sarjana & $8(24)$ & $19(30)$ & $27(28)$ \\
\hline Tidak diketahui & $1(3)$ & $2(3)$ & $3(3)$ \\
\hline \multicolumn{4}{|c|}{ Tingkat pendidikan ibu, n (\%) } \\
\hline Tidak sekolah & $0(0)$ & $0(0)$ & $0(0)$ \\
\hline SD & $6(18)$ & $14(22)$ & $20(21)$ \\
\hline SLTP & $5(15)$ & $13(21)$ & $18(19)$ \\
\hline SLTA & $14(42)$ & $18(29)$ & $32(33)$ \\
\hline D3 & $4(12)$ & $4(6)$ & $8(8)$ \\
\hline Sarjana & $3(9)$ & $12(19)$ & $15(16)$ \\
\hline Tidak diketahui & $1(3)$ & $2(3)$ & $3(3)$ \\
\hline \multicolumn{4}{|l|}{ Pekerjaan ayah, n (\%) } \\
\hline Tidak bekerja & $0(0)$ & $0(0)$ & $0(0)$ \\
\hline PNS/ABRI & $5(15)$ & $7(11)$ & $12(13)$ \\
\hline Buruh & $9(27)$ & $19(30)$ & $28(29)$ \\
\hline Petani & $0(0)$ & $1(2)$ & $1(1)$ \\
\hline Pedagang & $0(0)$ & $0(0)$ & $0(0)$ \\
\hline Swasta & $18(55)$ & $34(54)$ & $52(54)$ \\
\hline Tidak diketahui & $1(3)$ & $2(3)$ & $3(3)$ \\
\hline \multicolumn{4}{|l|}{ Pekerjaan ibu, n (\%) } \\
\hline Tidak bekerja & $25(76)$ & $53(84)$ & $78(81)$ \\
\hline PNS/ABRI' & $1(3)$ & $1(2)$ & $2(2)$ \\
\hline Buruh & $4(12)$ & $3(5)$ & $7(7)$ \\
\hline Petani & $0(0)$ & $0(0)$ & $0(0)$ \\
\hline Pedagang & $0(0)$ & $0(0)$ & $0(0)$ \\
\hline Swasta & $2(6)$ & $4(6)$ & $6(6)$ \\
\hline Tidak diketahui & $1(3)$ & $2(3)$ & $3(3)$ \\
\hline
\end{tabular}


Tabel 2. Karakteristik faktor prognosis penelitian

\begin{tabular}{|c|c|c|c|}
\hline Variabel & $\begin{array}{c}\text { Meninggal } \\
(\mathrm{n}=33)\end{array}$ & $\begin{array}{l}\text { Hidup } \\
(n=63)\end{array}$ & $\begin{array}{c}\text { Total } \\
(\mathrm{n}=96)\end{array}$ \\
\hline \multicolumn{4}{|l|}{ Usia, tahun, n (\%) } \\
\hline$<5$ & $16(49)$ & $15(24)$ & $31(32)$ \\
\hline$\geq 5$ & $17(51)$ & $48(76)$ & $65(68)$ \\
\hline \multicolumn{4}{|l|}{ Jenis kelamin, $\mathrm{n}(\%)$} \\
\hline Perempuan & $21(64)$ & $28(44)$ & $49(51)$ \\
\hline Laki-laki & $12(36)$ & $35(56)$ & $47(49)$ \\
\hline \multicolumn{4}{|l|}{ Satus Obesitas, n (\%) } \\
\hline Obes & $8(24)$ & $5(8)$ & $13(14)$ \\
\hline Non obes & $25(76)$ & $58(92)$ & $83(86)$ \\
\hline \multicolumn{4}{|l|}{ Tipe infeksi, n (\%) } \\
\hline Sekunder & $14(42)$ & $31(49)$ & $45(47)$ \\
\hline Primer & $2(6)$ & $6(10)$ & $8(8)$ \\
\hline Tidak diketahui & $17(52)$ & $26(41)$ & $43(45)$ \\
\hline \multicolumn{4}{|c|}{ Keterlambatan berobat, n (\%) } \\
\hline Ya & $7(21)$ & $17(27)$ & $24(25)$ \\
\hline Tidak & $26(79)$ & $46(73)$ & $72(75)$ \\
\hline \multicolumn{4}{|c|}{ Manajemen cairan, n (\%) } \\
\hline Tidak adekuat & $20(61)$ & $23(37)$ & $43(45)$ \\
\hline Adekuat & $9(27)$ & $37(59)$ & $46(48)$ \\
\hline Tidak diketahui & $4(12)$ & $3(4)$ & $7(7)$ \\
\hline \multicolumn{4}{|c|}{ Derajat trombositopenia, n (\%) } \\
\hline Berat & $16(49)$ & $37(59)$ & $53(55)$ \\
\hline Ringan & $17(51)$ & $26(41)$ & $43(45)$ \\
\hline \multicolumn{4}{|l|}{ Koagulopati, n (\%) } \\
\hline $\mathrm{Ya}$ & $28(85)$ & $6(10)$ & $34(35)$ \\
\hline Tidak & $4(12)$ & $36(57)$ & $40(42)$ \\
\hline Missing data & $1(3)$ & $21(33)$ & $22(23)$ \\
\hline \multicolumn{4}{|c|}{ Perdarahan mayor, n (\%) } \\
\hline Ya & $31(94)$ & $21(33)$ & $52(54)$ \\
\hline Tidak & $2(6)$ & $42(67)$ & $44(46)$ \\
\hline \multicolumn{4}{|c|}{ Syok berkepanjangan, n (\%) } \\
\hline $\mathrm{Ya}$ & $31(94)$ & $13(21)$ & $44(46)$ \\
\hline Tidak & $2(6)$ & $50(79)$ & $52(54)$ \\
\hline \multicolumn{4}{|l|}{ Ensefalopati, n (\%) } \\
\hline Ya & $30(91)$ & $17(27)$ & $47(49)$ \\
\hline Tidak & $3(9)$ & $46(73)$ & $49(51)$ \\
\hline \multicolumn{4}{|l|}{ Disfungsi hati, n (\%) } \\
\hline Ya & $23(70)$ & $6(10)$ & $29(30)$ \\
\hline Tidak & $9(27)$ & $40(63)$ & $49(51)$ \\
\hline Tidak diketahui & $1(3)$ & $17(27)$ & $18(19)$ \\
\hline \multicolumn{4}{|c|}{ Gagal hati fulminan, n (\%) } \\
\hline $\mathrm{Ya}$ & $19(58)$ & $0(0)$ & $19(20)$ \\
\hline Tidak & $12(36)$ & $47(75))$ & $59(61)$ \\
\hline Tidak diketahui & $2(6)$ & $16(25)$ & $18(19)$ \\
\hline \multicolumn{4}{|l|}{ DIC, n (\%) } \\
\hline Ya & $27(82)$ & $5(8)$ & $32(33)$ \\
\hline Tidak & $4(12)$ & $37(59)$ & $41(43)$ \\
\hline Tidak diketahui & $2(6)$ & $21(33)$ & $23(24)$ \\
\hline \multicolumn{4}{|l|}{ Edema paru, n (\%) } \\
\hline $\mathrm{Ya}{ }^{\mathrm{r}}$ & $9(27)$ & $14(22)$ & $23(24)$ \\
\hline Tidak & $24(73)$ & $49(78)$ & $73(76)$ \\
\hline \multicolumn{4}{|l|}{ Hipoksemia, n (\%) } \\
\hline $\mathrm{Ya}$ & $17(52)$ & $3(5)$ & $20(21)$ \\
\hline Tidak & $16(48)$ & $60(95)$ & $76(79)$ \\
\hline
\end{tabular}


hari ke-5.

Karakteristik dasar 96 kasus DSS yang terdiri dari 33 kasus meninggal dan 63 kasus hidup yang terpilih secara acak tertera pada Tabel 1.
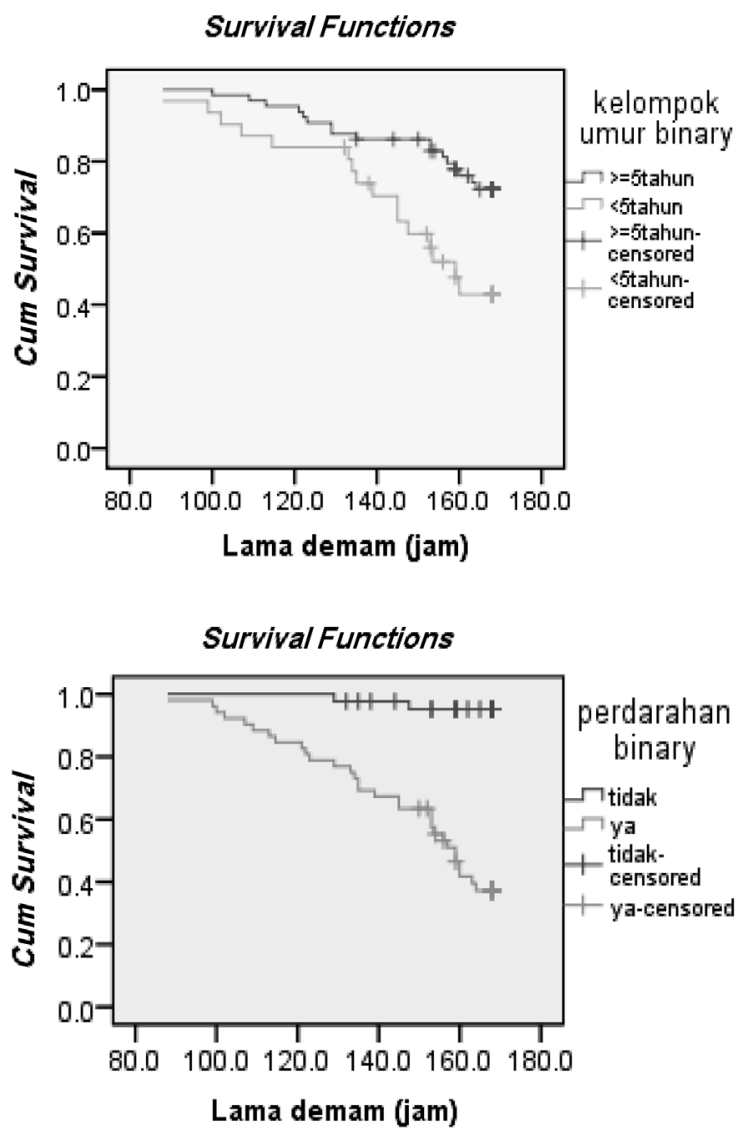

Pasien dengan status nutrisi obes yang meninggal $24 \%$. Terdapat $42 \%$ pasien DSS yang meninggal dengan tipe infeksi sekunder dimana IgM+ dan IgG+ atau IgG+. Pada kelompok pasien DSS meninggal
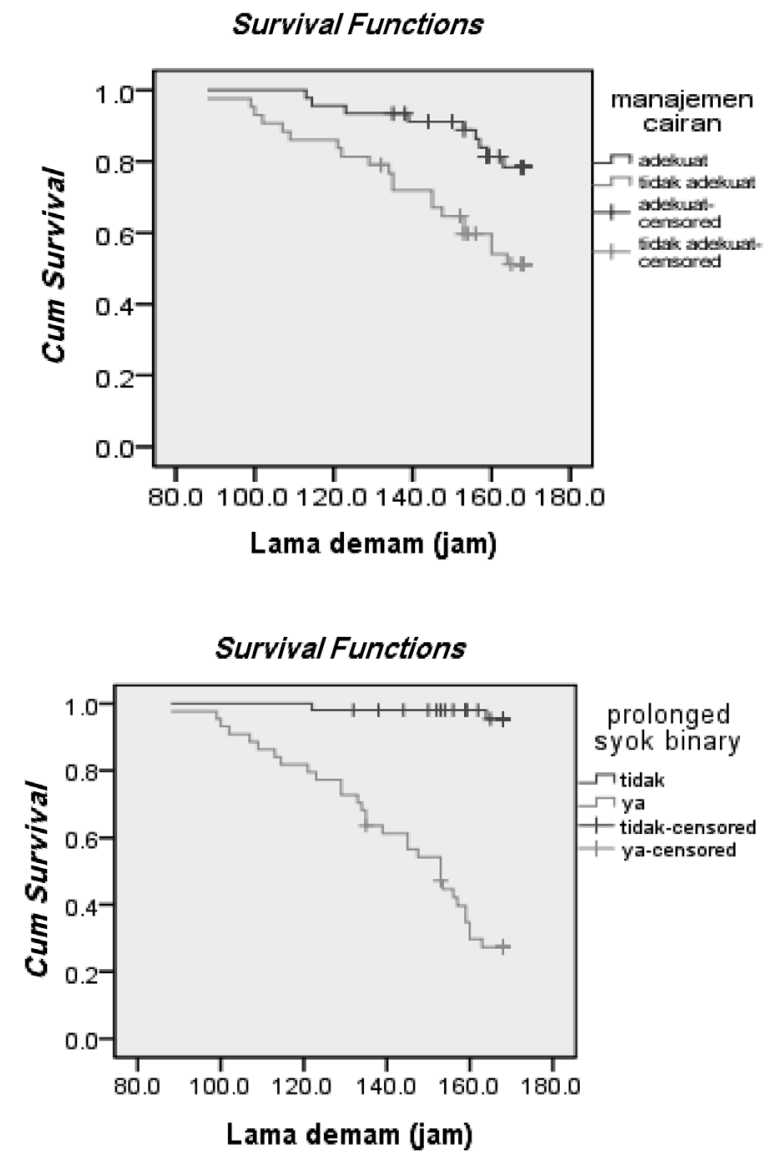

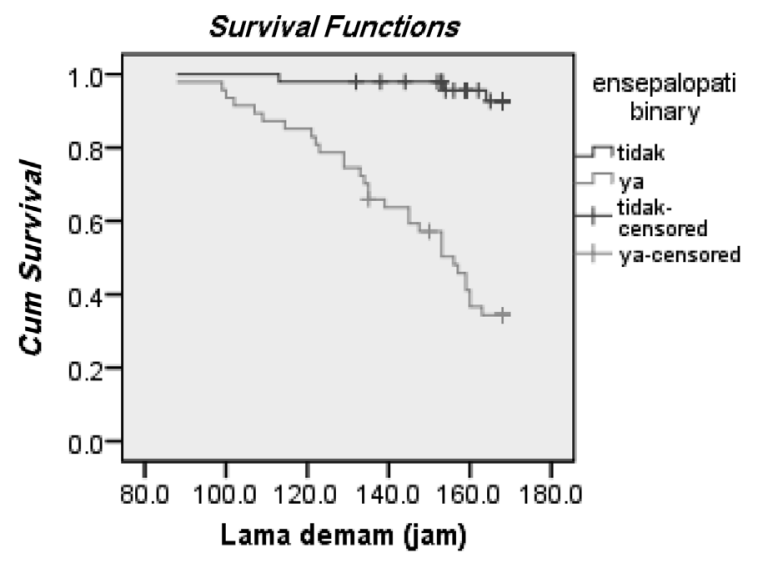

Gambar 1. Kurva Kaplan Meier berdasarkan usia (A), kurva Kaplan Meier berdasarkan manajemen cairan (B), kurva Kaplan Meier berdasarkan perdarahan mayor (C), kurva Kaplan Meier berdasarkan prolonged shock (D), kurva Kaplan Meier berdasarkan ensepalopati (E) 
Anggy Pangaribuan dkk: Faktor prognosis kematian sindrom syok dengue

Tabel 3. Analisis faktor prognosis kematian pada DSS menggunakan uji regresi Cox

\begin{tabular}{|c|c|c|c|}
\hline Variabel & $\begin{array}{c}\text { Analisis bivariat } \\
\text { HR (IK 95\%) }\end{array}$ & $\mathrm{p}$ & $\begin{array}{c}\text { Analisis multivariat } \\
\text { HR (IK 95\%) }\end{array}$ \\
\hline \multicolumn{4}{|l|}{ Usia, (tahun) } \\
\hline$\geq 5$ & 1 & 0,005 & 1 \\
\hline$<5$ & $2,662(1,338-5,296)$ & & $1,430(0,662-3,089)$ \\
\hline \multicolumn{4}{|c|}{ Manajemen cairan sebelum masuk RSS } \\
\hline Adekuat & 1 & 0,008 & 1 \\
\hline Tidak adekuat & $2,923(1,329-6,426)$ & & $2,658(1,146-6,161)$ \\
\hline \multicolumn{4}{|l|}{ Perdarahan mayor } \\
\hline Tidak & 1 & $<0,001$ & 1 \\
\hline Ya & $17,825(4,258-74,619)$ & & $8,233(1,741-38,831)$ \\
\hline Syok berkepanjangan & & & 1 \\
\hline Tidak & 1 & $<0,001$ & \\
\hline Ya & $29,094(6,936-122,032)$ & & $15,805(3,486-71,660)$ \\
\hline Ensefalopati & & & 1 \\
\hline Tidak & 1 & $<0,001$ & \\
\hline $\mathrm{Ya}$ & $15,071(4,589-49,499)$ & & $3,316(0,663-16,592)$ \\
\hline
\end{tabular}

$\mathrm{HR}=$ hazard ratio

yang datang terlambat berobat ada $21 \%$, yaitu pasien yang datang pertama kali baik ke RSUP Dr. Sardjito, RSUD, Puskesmas maupun ke tempat praktek dokter umum atau dokter spesialis anak dengan kondisi syok hipotensif. Di antara 24 kasus DSS yang terlambat berobat, 18 (75\%) merupakan pasien rujukan. Dari 33 pasien DSS yang meninggal, 20 (61\%) karena manajemen cairan yang tidak adekuat sebelum masuk RSUP Dr. Sardjito atau yang datang pertama kali ke RSUP Dr.Sardjito. Dari 43 pasien DSS dengan manajemen cairan yang tidak adekuat sebelum masuk rumah sakit Dr. Sardjito, 95\% karena jumlah cairan yang tidak adekuat yaitu $<10-20 \mathrm{ml} / \mathrm{kgbb}, 63 \%$ karena waktu pemberian yang tidak adekuat.

Enambelas (49\%) pasien dengan trombositopenia berat atau jumlah trombosit $<20.000 / \mathrm{uL}$ meninggal. Jumlah trombosit pada kelompok meninggal antara $4.000 \mathrm{~s} / \mathrm{d}$ 47.000/uL, sedangkan pada kelompok hidup antara $3.000 \mathrm{~s} / \mathrm{d} 96.000$ /uL. Tigapuluh satu (94\%) pasien DSS dengan perdarahan mayor yang bersumber dari saluran cerna terdiri dari hematemesis $23(70 \%)$, melena $3(9 \%)$, hematemesis dan melena 5 (15\%) meninggal. Duapuluh delapan (88\%) pasien dengan perdarahan mayor mengalami DIC. Terdapat 31 (94\%) pasien DSS yang meninggal karena syok berkepanjangan yang terjadi lebih dari 2 jam. Sejumlah 27 (84\%) pasien dengan prolonged shock mengalami DIC dan $16(80 \%)$ pasien syok berkepanjangan mengalami hipoksemia. Terdapat $91 \%$ pasien dengan ensefalopati yang ditandai dengan kejang atau penurunan kesadaran meninggal. Duapuluh tiga (70\%) pasien dengan disfungsi hati yaitu kadar SGPT $>200$ U/L meninggal. Kadar SGPT pada kelompok meninggal antara $32 \mathrm{~s} / \mathrm{d} 3486 \mathrm{U} / \mathrm{L}$, sedangkan pada kelompok hidup antara 9 s/d 2295 U/L (Tabel 2).

\section{Analisis faktor prognosis kematian pasien DSS}

Analisis regresi Cox bivariat dilakukan untuk mencari hazard ratio dari tiap variabel yang berdasarkan uji Kaplan Meier dianggap memenuhi asumsi proportional hazard, yaitu variabel yang pada kurva Kaplan Meier tidak memiliki garis kesintasan yang saling berpotongan. ${ }^{10}$ Dari 16 variabel yang dianalisis menggunakan kurva Kaplan Meier, 5 variabel yang memenuhi asumsi proportional hazard, yaitu usia, manajemen cairan sebelum masuk RSS, perdarahan mayor, syok berkepanjangan dan ensefalopati (Gambar 1). Kurva Kaplan Meier dari 11 variabel yang tidak memenuhi asumsi propotional hazard tidak dicantumkan dalam makalah ini.

Kelima faktor prognosis yang memenuhi proposional hazard di uji dengan Cox bivariat. Faktor prognosis dengan $\mathrm{p}<0,25$ pada uji bivariat di uji 
dengan Cox multivariat (Tabel 3).

Hasil analisis multivariat dengan metode regresi Cox yang bermakna sebagai variabel independen faktor prognosis terjadinya kematian pada DSS adalah manajemen cairan sebelum masuk rumah sakit Dr. Sardjito yang tidak adekuat (HR 2,658, IK 95\% $1,146 ; 6,616)$, perdarahan mayor (HR 8,223, IK 95\% $1,741 ; 38,831)$, dan syok berkepanjangan (HR 15,805, IK 95\% 3,486;71,660).

Anak DSS dengan manajemen cairan sebelum masuk rumah sakit Dr. Sardjito tidak adekuat mempunyai prognosis meninggal 2,7 kali lebih besar atau 38\% lebih tinggi dibandingkan anak dengan DSS dengan manajemen cairan sebelum masuk RSUP Dr. Sardjito yang adekuat. Anak dengan DSS yang mengalami perdarahan mayor mempunyai prognosis meninggal 8 kali lebih besar atau $88 \%$ lebih tinggi dibandingkan anak dengan DSS yang tidak mengalami perdarahan mayor. Anak dengan DSS yang mengalami prolonged shock mempunyai prognosis meninggal 16 kali lebih besar atau $88 \%$ lebih tinggi dibanding anak dengan DSS yang tidak mengalami prolonged shock.

\section{Pembahasan}

Angka kematian pasien DSS di RSUP Dr. Sardjito, Yogyakarta, cenderung menurun dari tahun 2006 (69\%) sampai 2010 (14\%), tetapi meningkat kembali tahun 2012 (43\%), sedangkan angka kematian (case fatality rate) di Indonesia cendrung menurun dengan stabil dari 41\% pada tahun 1968 menjadi kurang dari $2 \%$ sejak 2000 menjadi $1,21 \%$ pada 2004 , dan pada tahun 2008 angka kematian sudah menurun menjadi $0,86 \% .{ }^{4}$ Angka kematian yang tinggi ini disebabkan karena RSUP Dr. Sardjito merupakan rumah sakit rujukan. Pada penelitian kami frekuensi jenis kelamin laki-laki dan perempuan hampir sama 49\% dan 51\%. Penelitian DSS di RSAB Harapan Kita Jakarta dan Vietnam juga mendapatkan frekuensi yang hampir sama antara laki-laki dan perempuan..$^{11,12}$ Pada penelitian kami perempuan lebih banyak yang meninggal $(63,6 \%)$ dibandingkan laki-laki $(36,4 \%)$. Jenis kelamin perempuan juga lebih banyak yang meninggal pada penelitian di Semarang. ${ }^{9}$ Hal tersebut dimungkinkan karena laki-laki mempunyai kebiasaan untuk berobat lebih cepat dibandingkan perempuan. ${ }^{14}$ Pendapat lain mengatakan terdapat perbedaan secara imunologi antara anak perempuan dan laki-laki, perempuan memiliki respons imun yang kuat dan permeabilitas kapiler yang lebih tinggi sehingga lebih cepat mengalami syok. ${ }^{13,14}$ Penelitian kami menunjukkan mayoritas kasus DSS terjadi pada usia $\geq 5$ tahun yaitu 65 dari 96 subyek (67,7\%). Penelitian di Vietnam ditunjukkan 50\%-57\% kasus DSS berusia 5-14 tahun. ${ }^{15} \mathrm{Hal}$ tersebut kemungkinan karena terjadi perubahan pola transmisi dari transmisi di rumah beralih ke fasilitas publik seperti sekolah, mesjid, gereja, dan tempat bermain anak-anak. ${ }^{6}$ Sebagian besar pasien penelitian kami dirawat pada hari demam ke- 4 dan ke-5, sedangkan Wills dkk melaporkan sebagian besar subyek penelitian dirawat pada hari demam ke- 5 sampai ke-7.

Anak dengan DSS dengan manajemen cairan yang tidak adekuat sebelum masuk RSUP Dr. Sardjito atau masuk RSUP Dr. Sardjito pertama kali mempunyai prognosis meninggal 2,7 kali lebih besar atau 38\% lebih tinggi dibandingkan anak dengan DSS dengan manajemen cairan adekuat. Pada pasien dengan gejala syok yang dapat diketahui secara awal dan mendapat terapi cairan secara adekuat akan mengalami perbaikan secara cepat dan angka kematian yang rendah $0,2 \%$. Sekali terjadi syok dan tidak mendapat terapi yang baik maka angka kematian meningkat menjadi 12\%-44\%.,16 Pasien DBD dengan perdarahan dan hemokonsentrasi akan mengalami tanda syok lebih dini, tetapi dengan manajemen cairan yang tepat dan adekuat akan mengisi cairan intravaskular untuk mempertahankan hemodinamik yang stabil sehingga dapat mencegah perkembangan ke arah syok. ${ }^{3}$ Anak dengan SSD yang mengalami perdarahan mayor mempunyai prognosis meninggal 8 kali lebih besar atau $88 \%$ lebih tinggi dibandingkan anak dengan SSD yang tidak mengalami perdarahan mayor. Perdarahan pada infeksi dengue bisa disebabkan karena vaskulopati, trombositopenia, dan koagulopati. Perdarahan mayor yang biasanya berasal dari saluran cerna seperti hematemesis dan melena merupakan manifestasi perdarahan berat yang paling sering ditemukan. ${ }^{17}$ Pasien dengan perdarahan masif atau perdarahan tersembunyi yang tidak dapat diketahui, terutama perdarahan saluran cerna dapat mengakibatkan syok, gagal hati dan ginjal, dan gagal banyak organ sampai kematian. ${ }^{18}$ Anak dengan SSD yang mengalami syok berkepanjangan mempunyai prognosis meninggal 16 kali lebih besar atau 88\% lebih tinggi dibanding anak dengan SSD yang tidak mengalami prolonged shock. Disfungsi sirkulasi atau syok pada DBD disebabkan karena peningkatan 
permiabilitas vaskular sehingga terjadi kebocoran plasma, efusi cairan serosa ke rongga pleura dan peritoneum, hipoproteinuria, hemokonsentrasi dan hipovolemia yang mengakibatkan berkurangnya aliran balik vena, preload miokard, volume sekuncup dan curah jantung sehingga terjadi disfungsi sirkulasi dan penurunan perfusi organ. ${ }^{19}$ Kondisi syok pada DBD berhubungan dengan angka kematian yang tinggi (9\%) dan meningkat menjadi $47 \%$ jika syok tidak tertangani dengan baik dan menjadi profound shock. Syok berkepanjangan diikuti dengan asidosis metabolik, hipoksemia dan dapat menimbulkan DIC sehingga menyebabkan terjadinya perdarahan berat yang berakhir dengan kematian., 78,20

Pada penelitian kami manajemen cairan sebelum masuk RSUP Dr. Sardjito yang tidak adekuat merupakan faktor prognosis kematian pada SSD. Hal tersebut juga sama pada penelitian yang dilakukan di India oleh Kamath ${ }^{7}$ mendapatkan hasil bahwa penyebab kematian pada anak dengan dengue berat adalah syok refrakter berat, DIC, ARDS, gagal hati dan manifestasi neurologi. Kasus dengan syok berkepanjangan yang datang ke UGD didapatkan terapi cairan yang tidak adekuat dari rumah sakit sebelumnya dan disertai dengan perdarahan yang akan berlanjut menjadi syok persisten yang berakhir pada kematian. Begitu halnya juga pada penelitian di Bangkok pada pasien SSD dari kasus kematian di antaranya karena jumlah maupun tipe cairan yang tidak adekuat, terutama pada kasus rujukan seharusnya kondisi pasien distabilkan baik dari segi klinis dan laboratorium, begitu juga dengan tenaga medis yang ikut merujuk harus berkompeten dalam hal manajemen pasien DBD dengan syok. Rujukan yang cepat terutama pada pasien dengan dengue berat sangat direkomendasikan. ${ }^{15}$ Perdarahan mayor yang berasal dari saluran cerna merupakan faktor prognosis kematian pada penelitian ini. Pada penelitian di India, didapatkan hasil 18 pasien (16,5\%) mengalami perdarahan yang berat yang berasal dari saluran cerna dan mengakibatkan syok, 2 diantaranya disertai DIC dan meninggal. ${ }^{7}$ Penelitian yang dilakukan di Meksiko pada pasien dewasa ditemukan bahwa hematemesis dan melena merupakan faktor risiko kematian pada pasien DBD. ${ }^{21}$ Syok berkepanjangan merupakan faktor prognosis kematian pada penelitian ini, pada penelitian di Bangkok pasien dengan SSD yang meninggal 100\% mengalami syok berkepanjangan. ${ }^{15} \mathrm{Hal}$ tersebut juga didapatkan pada penelitian di India, di antara 39 pasien $(37,5 \%)$ yang mengalami syok persisten, 6 meninggal,
4 syok persisten dengan ARDS dan DIC, dan 2 syok persisten dan DIC.

Kekurangan dari penelitian kami yaitu data rekam medis yang kurang lengkap, belum ada prosedur tentang pemeriksaan serologis untuk penegakan diagnosis infeksi dengue dan kurang lengkapnya data tentang pencatatan manajemen cairan dan lama pemberian di rumah sakit sebelumnya yang seharusnya dicantumkan di surat rujukan. Penegakan diagnosis edema paru hanya dari data pemeriksaan klinis yang seharusnya juga dilakukan pemeriksaan penunjang foto $x$-ray paru. Tidak ada data mengenai jumlah perdarahan dalam catatan rekam medis. Hal tersebut akan menimbulkan bias dan memengaruhi hasil penelitian.

Manfaat penelitian yang bisa kita ambil bahwa angka kematian pasien DBD dengan syok masih tinggi khususnya di RSUP Dr. Sardjito, Yogyakarta yang merupakan rumah sakit rujukan. Hal tersebut memberikan kita informasi bahwa infeksi dengue masih merupakan masalah nasional yang angka kejadiannya semakin meningkat tiap tahunnya. Upaya yang dapat kita lakukan dalam rangka menurunkan angka kematian akibat SSD yaitu pengenalan dini tanda awal syok sehingga terapi cairan yang adekuat dapat kita berikan dan monitor yang ketat untuk mencegah syok berkepanjangan dan syok berulang juga penanganan komplikasi akibat infeksi dengue. Dalam hal merujuk pasien juga sebaiknya kondisi klinis harus stabil lebih dahulu sehingga layak rujuk, begitu juga halnya petugas medis yang ikut merujuk harus berkompetensi dalam hal menangani kegawatan terutama pada pasien DBD dengan syok selama perjalanan menuju rumah sakit rujukan.

\section{Kesimpulan}

Manajemen cairan sebelum masuk RSUP Dr. Sardjito yang tidak adekuat, perdarahan mayor, dan syok berkepanjangan merupakan faktor prognosis independen kematian pada anak dengan SSD.

\section{Daftar pustaka}

1. Bakshi AS. Dengue fever, DHF and DSS. Apollo Med 2007;4:111-7.

2. Shah GS, Das BK. Clinical and laboratory profile of 
dengue infection in children. Kathmandu University Med J 2006;4:40-3.

3. Tantracheewathorn T, Tantracheewathorn S. Risk factors of dengue shock syndrome in children. J Med Assoc Thai 2007;90:272-7.

4. Karyanti MR, Hadinegoro SR. Perubahan epidemiologi demam berdarah dengue di Indonesia. Sari Pediatri 2009;10:424-32.

5. Setiati TE, Wagenaar JFP, Kruif MD, Mairuhu ATA, Gorp ECM, Soemantri A. Changing epidemiology of dengue haemorrhagic fever in Indonesia. Dengue Bulletin 2006;30:1-14.

6. Raihan, Hadinegoro SRS, Tumbelaka AR. Faktor prognosis terjadinya syok pada demam berdarah dengue. Sari Pediatri 2010;12:47-52.

7. Kamath SR, Ranjit S. Clinical features, complications and atypical manifestations of children with severe form of dengue hemorrhagic fever in South India. Indian J Pediatr 2006;73:889-95.

8. Dhoria GS, Bhat D, Bains HS. Clinical profile and outcome in children of dengue hemorrhagic fever in North India. Iran J Pediatr 2008;18: 222-8.

9. Suharti C, Setiati TE, Gorp ECMV, Djokomoeljanto RJ, Trastotenojo MS, Meer JWMV. Risk factors for mortality in dengue shock syndrome. M Med Indones 2009;43:213-9.

10. Dahlan MS, penyunting. Analisis survival. Jakarta: Sagung Seto; 2009.

11. Dewi LP, Nurfitri E. Pediatric logistic organ dysfunction score as a predictive tool of dengue shock syndrome outcomes. Paediatr Indones 2012;52:72-7.

12. Wilss BA, Oragui EE, Stephens AC, dkk. Coagulation abnormalities in dengue hemorrhagic fever: Serial investigations in 167 Vietnamese children with dengue shock syndrome. CID 2002;35:277-85.

13. Whitehorn J, Simmons CP. The pathogenesis of dengue. Vaccine 2011;29:7221-8.

14. Anders KL, Nguyet NM, Chau NVV, Hung NY, Thuy TT, Lien LB. Epidemiological factors associated with dengue shock syndrome and mortality in hospitalized dengue patiens in Ho Chi Minh City, Vietnam. Am J Trop Med Hyg 2011;84:127-34.

15. Bunnag T, Kalayanarooj S. Dengue shock syndrome at the emergency room of Queen Sirikit national Institute of Child Health, Bangkok, Thailand. J Med Assoc Thai 2011;94:S57-S63.

16. Nhan NT, Phuong CXT, Kneen R. Acute management of dengue shock syndrome: A Randomized Double-Blind Comparison of 4 Intravenous Fluid Regimens in the First Hour. Clin Infect Dis 2001;32:204-13.

17. Soegijanto S, Budiyanto, Kartika, Taufik, Amor. Update management of dengue complication in pediatric. Ind J of Trop Infect Dis 2011; 2:1-11.

18. Chuansumrit A, Tangnararatchakit K. Pathophysiology and management of dengue hemorrhagic fever. TATM 2005;8:3-11.

19. Darwis D. Kegawatan demam berdarah dengue pada anak. Sari Pediatri 2003;4:156-62.

20. Malavige GN, Fernando S, Fernando DJ, Seneviratne SL. Dengue viral infection. Postgrad Med J 2004; 80:588601.

21. Navarrete J, Gomez H, Celis JG. Clinical profile of dengue hemorrhagic fever cases in Mexico. Salud Publica Mex 2005;47:193-200. 